\title{
Kırsallık Göstergeleri Bağlamında Türkiye İllerinin Kümelenmesi ve Devinimi
}

\section{Clustering and Motion of the Provinces in Turkey in the Context of Rural Indicators}

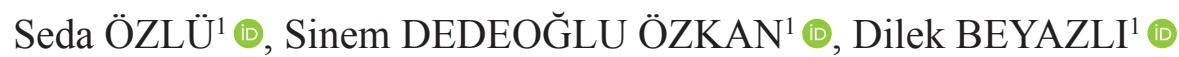 \\ ${ }^{1}$ Karadeniz Teknik Üniversitesi, Mimarlık Fakültesi, Şehir ve Bölge Planlama Bölümü, Trabzon, Türkiye
}

ORCID: S.Ö. 0000-0002-2568-7043; S.D.Ö. 0000-0002-1610-2242; D.B. 0000-0002-8182-5420

\section{öz}

Kırsallığın beşeri, sosyal, ekonomik ve ekolojik değerler yönünden çeşitliliği yerleşme ekosisteminin sürdürülebilirliği açısından önemlidir. Kırsallığın bu çok bileşenli yapısının; nüfus yoğunluğu, tarım veya doğal kaynaklar gibi tek boyutlu kriterler ile belirlenemeyeceği ve politika üretme konusunda yetersiz kalınacağı/kalındığı konusunda uzlaşı söz konusudur. Kırsallığa ilişkin yazında yer alan gerek kentsel/kırsal tanımının belirsizliği, gerekse tek değişkenli sınıflamaların yarattığı sınırıııkların tartışılması sonrasında Türkiye ölçeğinde kırsallığın sınıflandırılmasına ilişkin bir yaklaşım öngörülmüştür. Ülkenin bağlamsal gerçekleri ve var olan veri altyapısı, değişkenlerin seçimi ve yöntem konusunda belirleyici olmuştur.

Kent ve kırsal bölgelerin bütünleşik olarak yeniden değerlendirilmesini öngören bugünün mekânsal gelişim politikaları açısından yerleşmelerin sosyodemografik, ekonomik ve fiziksel bağlamlar gibi çok yönlü ve çoklu değişkenli süreçler ile ele alınması önemlidir. Çalışma ile Türkiye illeri kırsallığının seçilmiş sosyo-demografik, ekonomik ve fiziksel çevre değişkenleri yardımıyla sınıflandırılması amaçlanmıştır. NUTS-3 düzeyinde yapılan çalışmanın veri seti Türkiye İstatistik Kurumu ve CORiNE arazi örtüsü verilerinden elde edilmiş olup; yöntem olarak hiyerarşik olmayan kümeleme yöntemlerinden K-ortalamalar kullanılmıştır. Üç başlıkta ele alınan çalışmada il-altbölge-bölge düzeyinde yapılan mekânsal değerlendirmeler sonucunda 2006 yılından bugüne ülkede hissedilen doğu-batı arasındaki keskinliğin zaman içerisinde kırıldığı, bölgelerin ya da alt bölgelerin daha heterojen yapıya ulaştıkları görülmektedir.

Anahtar kelimeler: Kırsalıı, K-Ortalamalar Kümeleme Analizi, Türkiye (NUTS-3)

\section{ABSTRACT}

The diversity of rural areas in human, social, economic and ecological values is important for the sustainability of the settlement ecosystem. There is a consensus that the multi-component structure of rural areas cannot be determined by one-dimensional criteria such as population density, agriculture or natural resources and that the past/present policies are insufficient. After the discussion on the limitations of the definitions on the concepts of urban and rural and univariate classifications in the literature, a new approach on the classification of rural areas in Turkey was proposed. The nation's contextual realities and the current data infrastructure were decisive in the variable and methodology selection.

The present study aimed to classify the provincial rural areas in Turkey based on selected socio-demographic, economic and physical environment variables. The study was conducted on NUTS-3 level and the dataset was obtained from Turkey Statistical Institute and CORINE land cover data and K-means clustering, a non-hierarchical clustering method, was used. As a result of the spatial evaluations carried out at the provincial-subregional-regional level in the study, which are discussed under three main headings, it is seen that the sharpness of definition between the east and the west felt in the country has been broken over time.

Keywords: Rural areas, K-means Cluster analysis, Turkey (NUTS-3)

Başvuru/Submitted: 10.03.2020 • Revizyon Talebi/Revision Requested: 10.05.2020 • Son Revizyon/Last Revision Received: 20.05 .2020 • Kabul/Accepted: 31.05 .2020 - Online Yayın/Published Online: 00.00 .0000 


\section{EXTENDED ABSTRACT}

Rurality is important culturally, socially, politically, economically and especially in the context of the future / sustainability of rural areas. The distinction / relationship between urban and rural is one of the important topics of regional integration in Europe (Öğdül, 2010). Instead of the sharpness / clarity of the distinction between rural and urban areas with the multiple classifications required to produce policies on urban and rural areas that are diversified by developments, the degree of urbanity and rurality has begun to be discussed (Cloke, 1977; Cloke \& Edwards, 1986; OECD, 1993; ESPON, 2004; EUROSTAT, 2005). Despite the limited reliability of quantitative criteria, international organizations (such as OECD and EUROSTAT) adopt these criteria as they are particularly useful in the definition of rural areas, especially in comparison between regions or between states. Although there is no single definition that is accepted as urban or rural, it can be said that two of the common features in the European rural areas are low population density and agriculture has an important role in the local economy (Ballas, et al., 2003). Both the uncertainty of the definition of urban and rural, and the limitations of the definitions made with a single variable, directed the researchers to more complex methodologies and to determine / use new variables in classifying regions.

In terms of today's spatial development policies, which envisage the integrated re-evaluation of urban and rural areas, settlements need to be handled through multi-faceted and multivariate processes such as socio-demographic, economic and physical contexts. The aim of the study was to evaluate with selected socio-demographic, economic and physical variables the time-dependent change of rurality of the Turkey's provinces. In the first part of the study, the theoretical framework of the rural area, variable selection and clustering analysis in the method section, and in the last part, the evaluation of the time-dependent changes of the clusters that emerged after the analysis were made at the provincial, subregional and regional level.

The variables obtained from TUIK and CORINE land cover data constitute the dataset of this study conducted at NUTS-3 level. It has been compiled on the basis of those years for which TÜIKK and CORINE can provide common data in order to compare the rural structure of the provinces according to time period. Thus, the data set of the study consisted of 10 socio-demographic, 14 economic and 12 physical environment variables for 2006, 2012 and 2018.

The K-means method, one of the non-hierarchical clustering methods, was used in the study aiming to compare the time dependent change of the rural area at NUTS 3 level. Cluster analysis is a method used to analyze and organize multivariate or large scientific data (Everitt, 1993). According to Shih, et al. (2010), the purpose of clustering is to divide the data that can show a high degree of similarity into several groups. In order to make comparisons between variables and clusters of different years, a single number of clusters has been determined for each year. Considering 81 provinces, the number of clusters was calculated as six.

As a result of the K-Means cluster analysis, the variables of "population density" in the formation of socio-demographic clusters, "the rate of export within the country" in the formation of economic clusters and "proportion of artificial areas within the province" in the formation of physical clusters were the most effective factors. As a result of the clustering made at the provincial level by defining the rural indicators and the spatial evaluations at the provincial-subregional-regional level, it is observed that the sharpness of definition between the east and the west felt in the country has been broken over time, and the regions or sub-regions have reached a more heterogeneous structure. 


\section{GÍRIŞ}

Kırsallık; kültürel, sosyal, politik veya ekonomik açıdan ve özellikle kırsal alanların geleceği/sürdürülebilirliği bağlamında önem arz etmektedir. Kırsallığın ekonomik, doğal ve kültürel bileşenlerin bir kombinasyonu olarak görülmesi nüfus yoğunluğu, tarım veya doğal kaynaklar gibi tek boyutlu kriterler ile karakterize edilemeyeceği sonucunu ortaya koymaktadır (Avrupa Komisyon Raporu, 1999).

Kentsel-kırsal arasındaki ayrım / ilişki, Avrupa'daki bölgesel entegrasyonun önemli başlıklarından biridir (Öğdül, 2010). Tarımsal ve endüstriyel üretimdeki yenilikler, iklim değişiklikleri ve ulaştırma-iletişim teknolojilerindeki gelişmeler kentsel ve kırsal alanları farklı şekillerde etkilemekte; kentsel-kırsal etkileşimler üzerinde güçlü bir etkiye sahip olmaktadırlar (Leeuwen, 2015). Bu tür gelişmeler ile kentsel ve kırsal alanlar arasındaki ayrımın geçmişteki kadar keskin olmadığı, ancak birbirinden ayrıştırılmanın da kolay bir konu olmadığı anlaşılmaktadır (Combes ve Raybold, 2004; Gülümser, vd. 2010).

Yaşanan gelişmeler ile çeşitlenen kentsel ve kırsal alan hakkında politika üretmek için gerekli olan çoklu sınıflandırmalarla kırsal ve kentsel alanlar arasındaki ayrımın keskinliği/netliği yerine, kentsellik ve kırsallık dereceleri tartışılmaya başlanmıştır (Cloke, 1977; Cloke ve Edwards, 1986; OECD, 1993; ESPON, 2004; EUROSTAT, 2005).

Dünya literatüründe yer alan bu çalışmalar ülkemizde de ses bulmuş ve hem ulusal hem de yerel ölçekte birçok ampirik çalışma gerçekleştirilmiştir. "Koruma Odaklı Kırsal Alan Planlaması: Bir Model Önerisi" projesi ile de "bu ayrımın bir tür sorunu değil bir kademelenme sorunu olduğu" iddia edilmiştir (TÜBİTAK, 2014). Bu noktadan hareketle; Türkiye yazınında yer alan ülkemizdeki süreci özetlememize yardımcı olacak temel çalışmalardan kısaca bahsedersek;

- DPT tarafından 1982'de yapılan “Türkiye'de Yerleşme Merkezlerinin Kademelenmesi” çalışması, hem yerleşmelerin işlevlerine göre basamaklandırılması, hem de bunların etki alanlarının saptanması açısından ilginç sonuçlar ortaya koymuş, ülke ve bölge çapındaki etkilerine göre bölgelerin sınırları ile özekleri de belirlemiştir (Geray,1997).

- DPT tarafından 2004'te hazırlanan "İlçelerin SosyoEkonomik Gelişmiş̧lik Düzeyi Sıralaması" ile "ilçelerin genel gelişmişlik düzeyleri değerlendirilirken ilçe merkezleri yanında, ilçelere bağlı kırsal kesimlerin de bir bütün olarak değerlendirilmesi” yapılmıştır.
- Gülümser vd., $(2006,2010)$ tarafından yapılan çalışmalarının amacı "seçilmiş kırsal gelişme göstergeleri temelinde Türkiye'nin kırsal yapısını AB üye ülkeleri ile karşılaştırmalı olarak değerlendirmek ve $\mathrm{AB}$ içindeki yerini tanımlamaktır. Çalışma $\mathrm{AB}$ ülkelerinin kırsallık bağlamında homojen bir yapıya sahip olmadığını", Türkiye'nin Avrupa ortalamasından oldukça uzak kaldığını göstermektedir.

- Öğdül (2010), NUTS 4 düzeyinde gerçekleştirdiği çalışmasında kentsel-kırsal bağlamda bölgelerin çeşitliliğine vurgu yaparak, ülke genelinde kentlilik ve kırsallık derecelerini ortaya koymayı amaçlamıştır.

- Koruma Odaklı Kırsal Alan Planlaması: Bir Model Önerisi kapsamında hazırlanan Kırsal Alan Tipolojileri paketinin amacı; kırsal alan planlaması/kırsal gelişme kararlarında etkinliğin arttırılması, sürdürülebilir gelişmeyi hedefleyen kırsal alan tipolojisinin oluşturulmasıdır (TÜBİTAK, 2014).

Nicel kriterlerin sınırlı güvenirliğine rağmen, uluslararası kuruluşlar (OECD ve EUROSTAT gibi) kırsal bölgelerin tanımlanmasında özellikle bölgeleri, bölgeler arası veya eyaletler arası karşıllaştırmada yararlı olduğu için bu kriterleri benimsemektedir. Avrupa kırsal bölgelerinde ortak olan özelliklerden ikisinin düşük nüfus yoğunluğu ve tarımın yerel ekonomideki önemli rolü olduğu söylenebilir (Ballas, vd., 2003).

- Çoklu tanımlamanın ilk adımları 1964'te Avrupa İstatistik Konferansı'nda atılmış olup yerleşmeler nüfus büyüklüğüne göre "kentsel", "yarı kentsel" ve "kırsal" olarak üç sınıfa ayrilmıştır (BM, 1969).

- Cloke'un (1977) "kırsallık indeksi" çoklu gruplandırmayı içermekte olup; İngiltere'deki yerleşik alanların dışındaki alanları "aşırı kırsal", "orta kırsal", "orta dereceli olmayan" ve "aşırı kırsal olmayan" şeklinde tanımlamıştır.

- Endonezya'ya ait çoklu tanımlama örneğine göre; a) 5000 kişi/ $\mathrm{km}^{2}$ 'den fazla nüfus yoğunluğuna sahip, b) tarımsal üretim yapan hane halkının $\% 25$ 'ten az olduğu, c) 15 kentsel tesisten en az 8 'ini barındıran yerleşmeleri kentsel olarak tanımlanmaktadır (Hugo, vd., 2003). Bu üç kriterin değerlendirilmesi ile yerleşmeler "kentsel", "kırsal” ve "detaylı çalışmadan sonra tanımlanacak alanlar" olarak belirtilmektedir.

- Blunden vd. (1998) tarafindan yapilan sinıflama sonrası sinir ağ1 metodolojisinin geliştirilmesine ve uygulanmasına dayanan alternatif bir yaklaşım önerilmiştir.

- Leavy ve ark. (1999) İrlanda'nın 155 kırsal bölgesini sınıflandırmak için kümelenme analizini kullanmıştır. Nüfus sayımlarından elde edilen nüfus, ekonomi, eğitim ve hanehalkı verileri, çiftçilerin sayısı, işletmelerin tarım sayımına göre dağılımı hakkındaki veriler sınıflamada kullanılarak yerleşmeler beş sınıfa ayrılmıştır. 
- Petterson'de (2001) çalışmasında, İsveç'in kuzey bölgesinden 500 mikro bölgeyi sınıflandırmada küme analizi yöntemini kullanmıştır.

OECD ülkelerinde kentsel ve kırsal alanlar açısından uygun olabilecek bölgesel sınıflandırma çabaları sonucunda iki temel kırsal tipoloji yaklaşımı kabul görmüştür (Sotte, 2003; UN, 2007; Pizzoli ve Gong, 2007, Gülümser, vd. 2010). OECD ve AB tarafından hazırlanan bu iki yaklaşım ile diğer çalışmalar şöyle özetlenebilir;

1994 yılında OECD tarafından yürütülen kırsal gösterge çalışması mekânsal ve bölgesel yaklaşımların uzlaştırılmasına benzer şekilde işaret etmektedir. Kırsal bölge türleri arasındaki ayrım, şehir merkezlerinden coğrafi ve ekonomik uzaklığın bir fonksiyonu olarak düşünülebilir (Akder, 2003). Bu kırsal bölge türleri şöyle tanımlanır;

a) Ekonomik olarak bütünleşmiş kırsal alanlar; kent merkezine yakın, ekonomik ve demografik olarak büyüyen alanlardır.

b) Orta kırsal alanlar; genellikle tarıma bağımlı olabilen; ancak altyapı ile merkeze kolay erişim sağlayan alanlardır.

c) Uzak kırsal alanlar; az nüfuslu ve minimum altyapıya sahip alanlardır.

Ülkeler arasında aynı tür bölgelerin (kentsel veya kırsal) sosyo-ekonomik performanslarının karşılaştırılmasının, benzer özelliklerin ve gelişim yollarının tespitinde faydalı olduğu bilinmektedir. Bu tipoloji, OECD tarafından analitik çalışmalarda kullanılmış olup 90'lı yılların başında Kırsal Kalkınma Programının bir parçası olarak aralarındaki coğrafi farklılıkları göz önüne alarak üye ülkelerin bölgelerini, ulusal, bölgesel ve yerel olmak üzere üç hiyerarşik coğrafi ayrıntıya bölmek için temel bir kavramsal çerçeve sağlanmıştır (OECD, 2011; Pizzoli ve Gong, 2007). OECD'nin NUTS 5 düzeyinde yaptığ1 tanımlamada nüfus yoğunluğu esas alınmakta olup, yoğunluğun $150 \mathrm{kişi} / \mathrm{km}^{2}$ altındaki değerleri kırsal olarak tanımlanmaktadır. OECD yaklaşımı, bölgeleri yerel kırsal birimlerde yaşayan nüfusun yüzdesine göre "ağırlıklı olarak kentsel", "orta" veya "ağılıklı olarak kırsal" şeklinde sinıflandırmaktadır (OECD, 1994). Bir NUTS 3 bölgesinde ise sınıflama şu şekildedir:

- Baskın kırsal bölgeler: kırsal topluluklarda yaşayan nüfus $\% 50$ 'den fazladır.

- Önemli ölçüde kırsal bölgeler: kırsal topluluklarda yaşayan nüfus \%15-50'dır.

- Baskın kentsel bölgeler: kırsal topluluklarda yaşayan nüfus $\% 15$ 'ten azdir.
$\mathrm{AB}$ tarafından geliştirilen ve kırsal bölgeleri sınıflandırmaya yönelik diğer bir yaklaşımda da nüfus yoğunluğuna göre bir değerlendirme önerilmiştir. NUTS 5 düzeyindeki sınıflamada, yoğunluğun $100 \mathrm{kişi} / \mathrm{km}^{2}$ 'den düşük olduğu alanlar kırsal olarak tanımlanmaktadır. NUTS 3 düzeyindeki yerel sınıflama ise şu şekildedir;

- Yoğun nüfuslu bölgeler: her biri $500 \mathrm{kişi} / \mathrm{km}^{2}$ den fazla nüfus yoğunluğuna ve en az 50.000 bölge nüfusuna sahip bitişik belediye gruplarıdır.

- Orta yoğunluklu bölgeler: yoğun nüfuslu bir bölgeye ait olmayan, her biri $100 \mathrm{kişi} / \mathrm{km}^{2}$ den fazla nüfus yoğunluğuna sahip belediye gruplarıdır. Bölgenin toplam nüfusu en az 50.000 kişi veya yoğun nüfuslu bir bölgeye bitişik olmalıdır.

- Düşük nüfuslu bölgeler: yoğun nüfuslu veya orta dereceli olarak sinıflandırılmayan belediye gruplarıdır (Boscacci vd., 1999; EUROSTAT, 2010).

Avrupa Mekânsal Gelişim Programı (ESDP); kenti ve kırı ayrı ayrı ele almanın "modası geçmiş bir dualizm" olduğunu ileri sürmektedir (Coombes ve Raybold; 2004). Çalışmada "kentsel alanlar ile onları çevreleyen kırsal alanların işlevsel ilişkilerinin ve politikalarının ayrıştırılmasından uzaklaşmanın gerekliliğini" vurgulamaktadır (Avrupa Komisyonu, 1999). ESDP, kentselkırsal ortaklıklar gelişimini şiddetle savunarak; kentsel alanların sunduğu firsatların çoğu zaman kırsal alanlar için tamamlayıcı olduğunu, kasaba ve şehirlerin rakip olarak değil ortak olarak görülmesi gerektiğini belirtmektedir (Davoudi ve Stead, 2002). $\mathrm{Bu}$ tipolojideki sınıflar; büyük metropollerin egemen olduğu bölgeler, kentsel ve kırsal yoğunlukları yüksek olan çok merkezli bölgeler, yüksek kentsel yoğunluklu çok merkezli bölgeler, metropoliten alan etkisi altındaki kırsal alanlar, orta ve küçük kasaba ağları, uzak kırsal alanlar olarak tanımlanmaktadır.

ESPON projesi; kırsal alanların hangi dereceye kadar işlevsel olarak kent merkezlerine bağlı olduklarını ortaya koymaktadır. Sinıflandırma, "kırsal" ve "kentsel" bölgelerin birbirlerine olan bağımlılığını gösteren iki ana göstergeye dayanmakta olup; kategoriler yüksek kentsel nüfus, yüksek insan müdahaleleri ile düşük kentsel nüfus, düşük insan müdahaleleri arasında değiş̧mektedir (Bengs ve Schmidt, 2005). Nüfus yoğunluğu tarafindan belirlenen kentlilik derecesi ve arazi kullanım ile belirlenen insan müdahalesinin derecesine göre yerleşmelerin kırsallıkları sınıflandırılmaktadır.

Aralarındaki ilişkilere ve karşıllıklı bağımlılıklara sahip işlevsel ve mekânsal varlıklar olan kent ve kırsal bölgelerin; mekânsal gelişim stratejilerinin yerel ve bölgesel koşullarının, özelliklerinin ve gereksinimlerinin göz önünde bulundurması 
önerilerek bütünleşik biçimde yeniden değerlendirilmesi öngörülmektedir (Davoudi ve Stead, 2002).

Tarımsal ve endüstriyel üretimdeki yenilikler, iklim değişikliği, ulaştırma ve iletişimdeki gelişmeler kentsel ve kırsal alanları ve aralarındaki etkileşimi güçlü bir şekilde etkilemektedir (Leeuwen, 2015). Kırsallığın hangi değişken ve gösterge setleri ile belirlenmesi gerektiği sorunsalı çalışmaların güvenilirliğini etkileyen bir tartışmadır. Hem gelişmekte olan hem de gelişmiş dünyayla iletişim kuran uluslararası örgütler göstergeler için geliştirilecek dilin mümkün olduğunca ortak olması gerektiğini savunmaktadır (Akder, 2003). Kentsel veya kırsal olarak kabul edilmiş tek bir tanım olmamakla birlikte, Avrupa kırsal bölgelerinde ortak olan birkaç özellikten ikisinin göreceli olarak düşük nüfus yoğunluğu ve tarımın yerel ekonomideki önemli rolü olduğu söylenebilir (Scholz ve Herrmann, 2010; Ballas vd.,2003, Labrianidis, 2006). Bir başlangıç tanım olarak nüfus yoğunluğu kilit bir değişken olarak kabul edilse de (Pizzoli, 2017), düşük nüfus yoğunluğunun her zaman kırsal, yüksek nüfus yoğunluğunun da her zaman kentsel nüfus ile ilişkili olmaması kriterin kentsel ve kırsal bölgeler arasında sağlam bir sınıflandırma için yeterli olmadığını (Ballas vd., 2003) göstermektedir. OECD (1996) temel göstergeler setinde yer alan nüfus ve göç; ekonomik yapı ve performansı, sosyal refah ve eşitlik; çevresel sürdürülebilirliğin yanı sıra istihdam, nüfus, göç, konut koşulları, arazi kullanımı ve uzaklık kırsallığın tanımlanmasında kullanılmıştır. Cloke’un (1977) öngördüğü şekilde "tarım arazisi veya kırsal alandaki yerleşim alanı değişkenlerini de barındıran çalışmalar bulunmaktadır.

Gerek kentsel ve kırsal tanımının belirsizliği, gerekse tek değişken ile yapılan tanımların yaratacağı sınırlılıklar araştırmacıları bölgeleri sınıflamada daha karmaşık metodolojilere ve yeni değişkenler belirlemeye/kullanmaya yöneltmiştir. $\mathrm{Bu}$ bağlamda seçili çalışmalar kapsamında

Tablo 1. Yurt içi ve yurtdışı yazında kırsallığın sınıflamasında kullanılan değişkenler.

Table 1. Variables used in the classification of rurallity in domestic and international literature.

\begin{tabular}{|c|c|c|c|c|c|c|c|c|c|c|}
\hline Değişkenler & 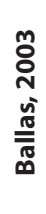 & 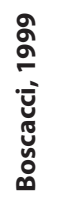 & 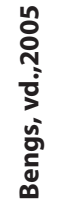 & $\begin{array}{l}\frac{1}{\alpha} \\
\frac{0}{0} \\
\frac{0}{0}\end{array}$ & 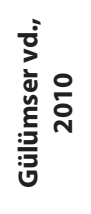 & 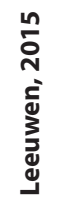 & 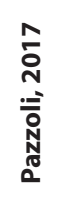 & $\begin{array}{l}0 \\
0 \\
0 \\
\overline{:} \\
: 0 \\
: 0 \\
: 0\end{array}$ & 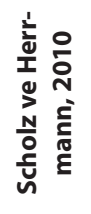 & 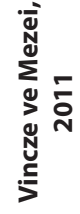 \\
\hline Nüfus & $\mathrm{x}$ & & & & $\mathrm{x}$ & $\mathrm{X}$ & $\mathrm{X}$ & $\mathrm{X}$ & & \\
\hline Nüfus Yoğunluğu & $x$ & & $x$ & $\mathrm{x}$ & & & $\mathrm{x}$ & $\mathrm{x}$ & $\mathrm{x}$ & $\mathrm{x}$ \\
\hline Nüfus Artışı & & & & $x$ & $x$ & & & & $x$ & $x$ \\
\hline Yaş Gruplarına Göre Nüfus Oranı & & & & $x$ & & & & & & $x$ \\
\hline Kaba Doğum ve Ölüm Oranı & $x$ & & & & $x$ & & & & & \\
\hline Bağımlııık Oranı & & & & & & & & $x$ & & $x$ \\
\hline Göç Oranı & & & & $x$ & & & & & & \\
\hline Eğitim / Okullaşma Oranları & & & & & $\mathrm{x}$ & & & $x$ & & \\
\hline Meslek & & & & $x$ & & & & & & \\
\hline GSYIH & $x$ & & & & & $x$ & & & $\mathrm{X}$ & \\
\hline Kişi Başı GSYiH & $x$ & & $x$ & & & $x$ & & & & \\
\hline Sektörlere Göre İstihdam / Çalışan Oranı & $x$ & $\mathrm{x}$ & & & $\mathrm{x}$ & $x$ & $\mathrm{x}$ & $\mathrm{x}$ & $x$ & \\
\hline Sektörlere Göre Katma Değerin Toplam İçindeki Oranı & $\mathrm{x}$ & $x$ & & & & & & & $X$ & \\
\hline Toplam İşsizlik & $\mathrm{x}$ & & & & & & & & $\mathrm{x}$ & \\
\hline Gelir & & & & & $\mathrm{X}$ & & & $\mathrm{X}$ & & $\mathrm{X}$ \\
\hline Toplam Alan & $x$ & & & & & & $x$ & & & \\
\hline Tarım Alanının Toplam Alana Oranı & & $\mathrm{x}$ & $\mathrm{X}$ & & $\mathrm{X}$ & & $\mathrm{x}$ & & $\mathrm{x}$ & $\mathrm{x}$ \\
\hline Yapay Alanlar \%'si & & & $\mathrm{x}$ & & & & & & $x$ & \\
\hline Orman Alanları \%'si & & & $\mathrm{X}$ & & & & & & $\mathrm{x}$ & \\
\hline Ekilebilir Arazinin Toplam Tarımsal Alandaki Payı & & $\mathrm{x}$ & & & & & & & & $x$ \\
\hline Süreklilik Göstermeyen Alanın Toplam Tarımsal Alana Oranı & & $x$ & & & & & & & & \\
\hline Tarımsal Üretim & & & & & & & & $x$ & & \\
\hline Kentleşme Oranı & & & & & & & & $x$ & & \\
\hline Yoğunluğa Göre Hanehalkı Oranları & $x$ & & & & & & & & & \\
\hline Konut Sayısı / Oranı & & $\mathrm{x}$ & & $\mathrm{x}$ & $\mathrm{x}$ & & $\mathrm{x}$ & & & $\mathrm{x}$ \\
\hline Konut Olanakları & & & & $x$ & & & & & & \\
\hline Turizm Otel ve Yatak Sayısı & $\mathrm{x}$ & & & & & $\mathrm{x}$ & & & $\mathrm{x}$ & \\
\hline Erişilebilirlik / Erişim Süresi & $x$ & & $\mathrm{x}$ & $\mathrm{x}$ & & & & $\mathrm{x}$ & & $\mathrm{x}$ \\
\hline Belirli Nüfus Büyüklüğüne Uzaklık & & & & $\mathrm{x}$ & & & & & & \\
\hline Şube Bankası Sayısı & & & & & & & & $\mathrm{x}$ & & \\
\hline Elektrik Tüketimi & & & & & $\mathrm{x}$ & & & & & $\mathrm{x}$ \\
\hline Co2 Emisyonu (Kişi Başı) & & & & & $\mathrm{x}$ & & & & & $\mathrm{x}$ \\
\hline
\end{tabular}


kırsallığın tanımlama, sinıflama ve tipoloji oluşturma süreçlerinde kullanılan değişkenler Tablo 1'de özetlenmiştir.

\section{AMAÇ VE YÖNTEM}

Türkiye illeri kırsallığının zamana bağlı değişimlerinin seçilmiş değişkenler yardımıyla sosyo-demografik, ekonomik ve fiziksel bağlamda değerlendirmek amaçlanmaktadır. Çalışmada kırsallığın kuramsal çerçevesine, değişken seçimine, kümeleme analizine ve analiz sonrasında ortaya çıkan kümelerin zamana bağlı değişiminin il, alt bölge ve bölge düzeyinde değerlendirilmesine yer verilmiştir.

Kümeleme analizi çok değişkenli veya büyük bilimsel verileri analiz etmek ve düzenlemek için kullanılan bir yöntemdir (Everitt,1993). Shih, vd.’ya (2010) göre kümelemenin amac1, birbirine yüksek derecede benzerlik gösterebilecek verilerin aynı grupta olacak şekilde birkaç gruba bölünmesidir. Bir gruptaki benzerlik derecesi, her eksenin özelliğini temsil ettiği sistemle arasındaki mesafeyle tanımlanır. Birbirine yakın toplulukların aynı kümede gruplandırılma olasılıkları daha yüksektir (Vıncze ve Mezei, 2011). Başka bir ifade ile kümeleme analizi, veri setinin farklı sınıflar veya gruplar içerip içermediğini ve içeriyorsa bu grupların tespit edilmesini amaçlar (Hajizadeh, vd., 2010).

NUTS 3 düzeyinde kırsallığın zamana bağlı değişimini karşılaştırmayı amaçlayan çalışmada hiyerarşik olmayan kümeleme yöntemlerinden biri olan ve veri kümesini k gruba müdahalesiz olarak ayırmada yaygın olarak kullanılan K-ortalamalar yöntemi kullanılmıştır. Yöntem k başlangıç küme merkezlerini seçerek başlar. Ardından her bir örneğin en yakın küme merkezine atanması ve her bir küme merkezinin onu oluşturan örneklerin ortalamasına göre güncellenmesi ile uygulanır (Wagstaff, vd., 2001). K-ortalamalar kümeleme algoritması üç aşamadan oluşmakta olup başlangıç aşamasında nesneler rasgele olarak k kümesine ayrılmaktadır. Tekrarlama aşamasında; her bir kümenin merkezini verilerin ortalaması olarak hesapladıktan sonra her bir nesnenin her kümeye kareli öklid uzaklığı hesaplanır. Bu ikinci adım, hata fonksiyonun hesaplanması ile tamamlanır. Son adım ise; hiçbir nesnenin kümeleri hareket ettirmediği son aşama olan "durma aşamasına" kadar devam eder (Tekin, 2018).

Kümeleme analizinde geçerli ve anlamlı sonuçlara ulaşabilmek için iki koşulun sağlanması gerekir. Bunlar; önemli değişkenlerin seçilmesi ve küme sayısının doğru belirlenmesidir (Punj ve Stevvart, 1983). Küme sayısına karar vermek için geliştirilen en temel ölçütlerden biri (Tatlıdil, 1992; Çakmak vd, 2005) şöyledir: $\mathrm{N}$ gözlem sayısını göstermek üzere küme sayısı $\mathrm{k}=(\mathrm{N} / 2)^{1 / 2}$ ifadesi ile hesaplanabilir. Ayrıca, kümeleme analizde standartlaştırılmış ya da standartlaştırılmamış değerler de kullanılabilir.

Çalışmada farklı yıllara ait değişkenler ile oluşacak kümeler arasında karşılaştırma yapılabilmesi amacıyla her yıl için ortak bir küme sayısı belirlenmiş olup, 81 il ele alındığında küme sayısı altı olarak hesaplanmıştır. Değişkenlerin belirlenmesinin ardından küme sayısının hesaplanması ile K-Ortalamalar kümeleme analizi SPSS programı yardımıyla gerçekleştirilmiştir. Kümeleme analizi yöntemi standartlaştırılmış ve standartlaştırılmamış verilerle yapılmış olup; haritalama ve yorumlama aşamasında standartlaştırılmış veriler ile oluşturulan kümeler kullanılmıştır.

Çalışmanın takip eden aşamasında yurt içi / yurt dışı yazından elde edilen kırsallığı anlatmada kullanılan değişkenler belirlenmiş

Tablo 2. Kırsallığı anlatan ve çalışmada kullanılan değişkenler ile veri kaynakları.

Table 2. Variables describing the rurality and used in the study and data sources.

\begin{tabular}{|c|c|c|}
\hline Sosyo-Demografik Değişkenler ${ }^{1}$ & Ekonomik Değişkenler & Fiziksel Değişkenler \\
\hline Toplam nüfus (TÜIK) & Kişi başına düşen Gayri Safi Yurt İçi Hâsıla (GSYiH) (TÜiK) & Toplam ilin oranı (CORINE) \\
\hline Köy nüfusu (TÜiK) & Tarım sektörü GSH oranı* & İl içindeki şehir yapısı oranı (CORINE) \\
\hline Yıllık nüfus artış hızı (TÜíK) & Sanayi sektörü GSH oranı* & İl içindeki tarımsal alan oranı (CORINE) \\
\hline Nüfus yoğunluğu (TÜiK) & Hizmet sektörü GSH oranı* & İl içindeki sürekli yapılaşma göstermeyen alan oranı (CORINE) \\
\hline Kırsallık oranı* & Kişi başına düşen ithalat oranı (TÜíK) & İl içindeki orman ve yarı doğal alan oranı (CORINE) \\
\hline Genç bağımlılık oranı (TÜİK) & Kişi başına düşen ihracat oranı (TÜiK) & İl içindeki yapay alanların oranı (CORINE) \\
\hline Yaşlı bağımlılık oranı (TÜIK) & Ülke içindeki ithalat oranı* & İle düşen köy yolu* \\
\hline Aktif nüfus (24-44 yaş) oranı* & Ülke içindeki ihracatın oranı* & İle düşen kara ve demir yolu* \\
\hline 65 yaş üstü oranı (TÜiK) & Tarımsal üretimin ülkedeki oranı* & Birim nüfusa düşen otomobil sayısı* \\
\hline \multirow[t]{5}{*}{ Ortalama hane büyüklüğü } & Kırsal nüfusa düşen tarımsal üretim* & Birim nüfusa düşen hastane sayısı* \\
\hline & Hektara düşen büyük ve küçükbaş hayvan sayısı* & Tarımsal alan içindeki ekilen alan oranı (TÜíK) \\
\hline & Ülke içindeki organik üretim oranı* & Tarımsal alan içindeki organik tarım alanı oranı (TÜiK) \\
\hline & Organik üretim yapan çiftçi oranı* & \\
\hline & Ülke içindeki örtü altı tarım oranı* & \\
\hline
\end{tabular}

*TÜIK ve CORINE sisteminden elde edilen veriler kullanılarak yazar tarafından oluşturulmuştur.

'ADNKS'de sosyo-demografik göstergelerin 2006 yılında toplanmaması nedeniyle 2007 verileri kullanılmıştır. 
ve değişkenlerin Türkiye illerindeki değerlendirmesi hakkında bilgi verilmiştir. Türkiye NUTS 3 düzeyinde yapılan çalışmada kırsal alanın sosyo-demografik ve ekonomik yapısını anlatan değişkenler Türkiye İstatistik Kurumu'nun (TÜIK) bölgesel ve il düzeyindeki verilerinden; kırsal alanın fiziksel yapısını anlatan değişkenler ise CORINE arazi örtüsü ile TÜİK verilerinden elde edilmiştir. İllerin kırsal yapısının zamana bağlı olarak karşılaştırılabilmesini sağlamak amacıyla TÜİK ve CORINE'nin ortak veri sağlayabildiği yıllar temel alınarak derlenmiştir. Böylece çalışmanın veri setini 2006, 2012 ve 2018 yıllarına ait 10 sosyo-demografik, 14 ekonomik ve 12 fiziksel çevre değişkeni oluşturmuştur (Tablo 2).

\section{BULGULAR}

Çalışmanın bu bölümünde 2006, 2012 ve 2018 yıllarına ait "sosyo-demografik", "ekonomik" ve "fiziksel çevre” değişkenleri kullanılarak yapılan K-ortalamalar kümeleme analizi sonucunda Türkiye illerinin kırsallık durumları üç başlıkta ele alınmış olup; kümeleme analizi sonuçları ve mekânsal dağılımları haritalanarak yorumlanmıştır.

a)Sosyo-Demografik Kümeleme; Belirlenen 10 sosyodemografik değişken ile 2007, 2012, 2018 yılları için yapılan K-ortalamalar kümeleme analizi sonucunda elde edilen ANOVA tabloları kullanılan değişkenlerin anlamlı olup olmadıklarını belirlemekte olup; kullanılan tüm değişkenlerin anlamlı olduğu görülmektedir. "Nüfus yoğunluğu" ve "toplam nüfus" -F değerine göre- kümelerin belirlenmesinde en önemli değişkenlerdir (Tablo 3).

2007 yılı sosyo-demografik değişkenler kullanılarak yapılan kümeleme analizine göre iller genel olarak mekânsal yakınlığa

Tablo 3. Türkiye illeri kırsallığının sosyo-demografik açıdan kümelenmesi

Table 3. Socio-demographic clustering of Turkey provinces rurality

\begin{tabular}{|c|c|c|}
\hline & Küme & Kümede Yer Alan İler \\
\hline \multirow{6}{*}{2007 yılı } & $\begin{array}{l}\text { 1. Küme } \\
\text { (12 il) }\end{array}$ & Ağrı, Batman, Bitlis, Diyarbakır, Hakkâri, Iğdır, Mardin, Muş, Siirt, Şanlıurfa, Şırnak, Van \\
\hline & $\begin{array}{l}\text { 2. Küme } \\
\text { (15 il) }\end{array}$ & Adana, Ankara, Antalya, Bursa, Eskişehir, Gaziantep, İzmir, Kayseri, Kocaeli, Konya, Mersin, Osmaniye, Sakarya, Tekirdağ, Yalova \\
\hline & $\begin{array}{l}\text { 3. Küme } \\
\text { (32 il) }\end{array}$ & $\begin{array}{l}\text { Adıyaman, Afyonkarahisar, Aksaray, Amasya, Ardahan, Bayburt, Bilecik, Bingöl, Çorum, Edirne, Elazığ, Erzincan, Erzurum, Isparta, Kara- } \\
\text { bük, Karaman, Kars, Kırıkkale, Kırklareli, Kırşehir, Kilis, Kütahya, Malatya, Nevşehir, Niğde, Ordu, Rize, Sivas, Tokat, Tunceli, Uşak, Yozgat }\end{array}$ \\
\hline & $\begin{array}{l}\text { 4. Küme } \\
\text { (10 il) }\end{array}$ & Artvin, Bartın, Bolu, Burdur, Çanakkale, Çankırı, Giresun, Gümüşhane, Kastamonu, Sinop \\
\hline & $\begin{array}{l}\text { 5. Küme } \\
\text { (11 il) }\end{array}$ & Aydın, Balıkesir, Denizli, Düzce, Hatay, Kahramanmaraş, Manisa, Muğla, Samsun, Trabzon, Zonguldak \\
\hline & $\begin{array}{l}\text { 6. Küme } \\
\text { (1 il) }\end{array}$ & İstanbul \\
\hline \multirow{6}{*}{2012 yılı } & $\begin{array}{l}\text { 1. Küme } \\
\text { (12 il) }\end{array}$ & Adıyaman, Ağrı, Batman, Bingöl, Bitlis, Hakkâri, Iğdır, Kars, Mardin, Muş, Siirt, Şırnak \\
\hline & $\begin{array}{l}\text { 2. Küme } \\
\text { (14 il) }\end{array}$ & Adana, Ankara, Antalya, Bursa, Eskişehir, Gaziantep, İzmir, Kayseri, Kocaeli, Konya, Mersin, Osmaniye, Sakarya, Tekirdağ \\
\hline & $\begin{array}{l}\text { 3. Küme } \\
\text { (32 il) }\end{array}$ & $\begin{array}{l}\text { Afyonkarahisar, Aksaray, Aydın, Balıkesir, Bilecik, Bolu, Çanakkale, Denizli, Düzce, Elazığ, Erzincan, Erzurum, Isparta, Kahramanmaraş, } \\
\text { Karabük, Karaman, Kırklareli, Kütahya, Malatya, Manisa, Muğla, Nevşehir, Niğde, Ordu, Rize, Samsun, Tokat, Trabzon, Tunceli, Uşak, } \\
\text { Yalova, Zonguldak }\end{array}$ \\
\hline & $\begin{array}{l}\text { 4. Küme } \\
\text { (18 il) }\end{array}$ & $\begin{array}{l}\text { Amasya, Ardahan, Artvin, Bartın, Bayburt, Burdur, Çankırı, Çorum, Edirne, Giresun, Gümüşhane, Kastamonu, Kırıkkale, Kırşehir, Kilis, } \\
\text { Sinop, Sivas, Yozgat }\end{array}$ \\
\hline & $\begin{array}{l}\text { 5. Küme } \\
\text { (4 il) }\end{array}$ & Diyarbakır, Hatay, Şanlıurfa, Van \\
\hline & $\begin{array}{l}\text { 6. Küme } \\
\text { (1 il) }\end{array}$ & İstanbul \\
\hline \multirow{6}{*}{2018 yılı } & $\begin{array}{l}\text { 1. Küme } \\
\text { (12 il) }\end{array}$ & Ağrı, Batman, Bitlis, Diyarbakır, Hakkâri, ığdır, Mardin, Muş, Siirt, Şanlıurfa, Şırnak, Van \\
\hline & $\begin{array}{l}\text { 2. Küme } \\
\text { (24 il) }\end{array}$ & $\begin{array}{l}\text { Adana, Ankara, Antalya, Aydın, Bilecik, Bursa, Denizli, Erzurum, Eskişehir, Gaziantep, Hatay, İzmir, Kahramanmaraş, Kayseri, Kocaeli, } \\
\text { Konya, Malatya, Manisa, Mersin, Muğla, Sakarya, Samsun, Tekirdağ, Trabzon }\end{array}$ \\
\hline & $\begin{array}{l}\text { 3. Küme } \\
\text { (16 il) }\end{array}$ & $\begin{array}{l}\text { Adıyaman, Afyonkarahisar, Aksaray, Bingöl, Düzce, Elazığ, Gümüşhane, Karaman, Kars, Kilis, Kütahya, Nevşehir, Niğde, Osmaniye, } \\
\text { Uşak, Zonguldak }\end{array}$ \\
\hline & $\begin{array}{l}\text { 4. Küme } \\
\text { (27 il) }\end{array}$ & $\begin{array}{l}\text { Amasya, Ardahan, Artvin, Balıkesir, Bartın, Bayburt, Bolu, Burdur, Çanakkale, Çorum, Edirne, Erzincan, Giresun, Isparta, Karabük, } \\
\text { Kastamonu, Kırıkkale, Kırklareli, Kırşehir, Ordu, Rize, Sinop, Sivas, Tokat, Tunceli, Yalova, Yozgat }\end{array}$ \\
\hline & $\begin{array}{l}\text { 5. Küme } \\
\text { (1 il) }\end{array}$ & Çankırı \\
\hline & $\begin{array}{l}\text { 6. Küme } \\
\text { (1 il) }\end{array}$ & İstanbul \\
\hline
\end{tabular}

*Altı çizili iller kümeleme analizinde en düşük "distance değerine sahip olan ve bulunduğu kümeyi en iyi temsil eden illerdir. 


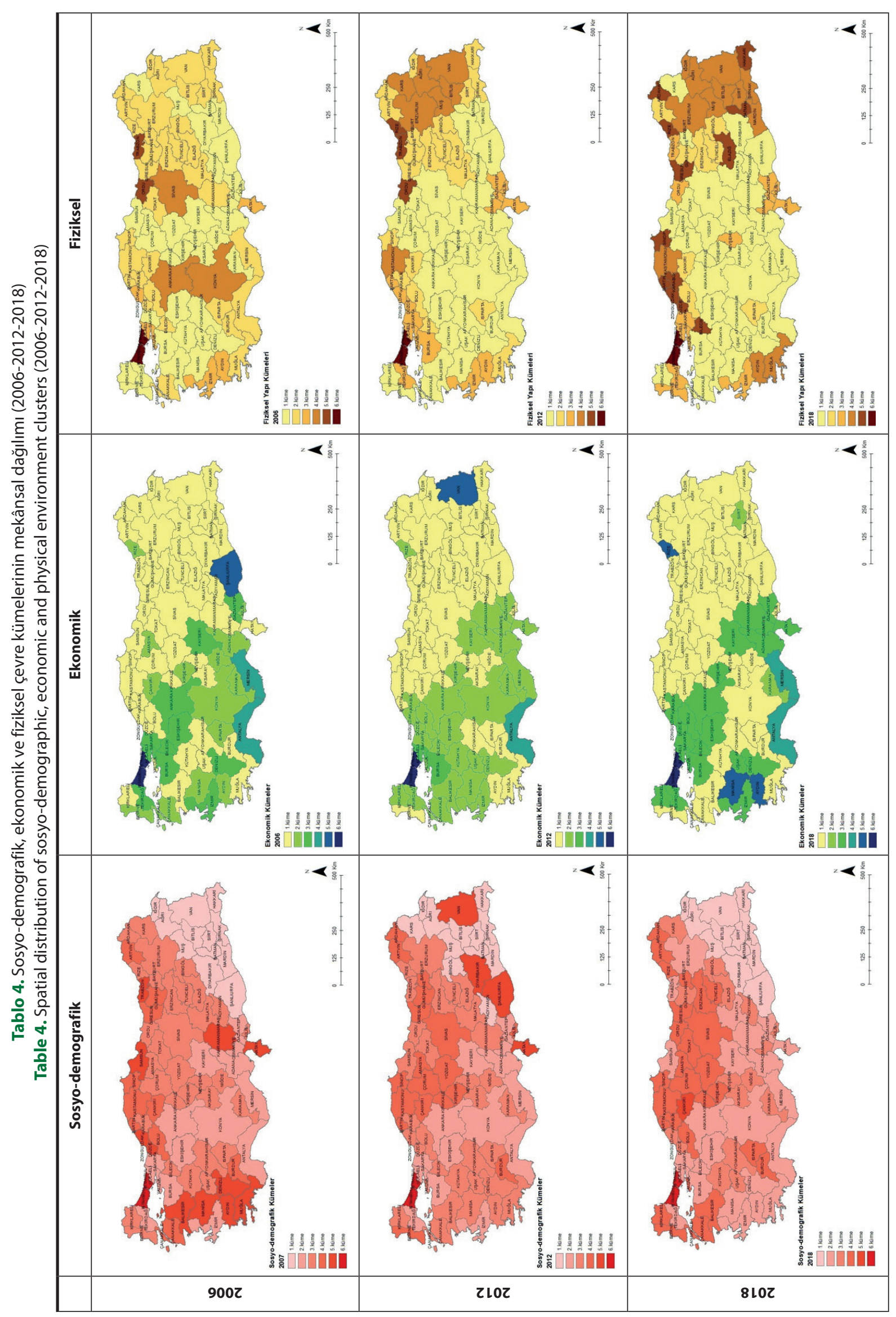


sahip komşu illerle beraber homojen bir yapı oluşturmaktadır. Türkiye genelinde bölgeler incelendiğinde (Tablo 3, Tablo 4);

- İstanbul (TR10) ve TR 31'in (İzmir alt bölgesinin) bölge içinde tek başına bir kümede,

- Orta Anadolu bölgesinin homojen yapıda olduğu, Kayseri ilinin bu kümeden ayrılarak TR62 alt bölgesindeki AdanaMersin illeri ile aynı kümede yer aldığı,

- Karadeniz Bölgesinde TR90 alt bölgesinde Trabzon, TR83 alt bölgesinde Samsun illerinin komşu illerden farklı bir kümede yer aldığı,

- Güneydoğu Anadolu Bölgesi'nin homojen bir sosyal yapıya sahip olduğu,

- TR63 Hatay alt bölgesinde Kahramanmaraş ve Hatay'ın aynı kümede, Osmaniye'nin diğer komşu illeri olan Adana ve Gaziantep'le aynı kümede yer aldığı görülmektedir.

2012 y1lı verilerine göre oluşan sosyo-demografik bağlamdaki kümeler incelendiğinde (Tablo 3, Tablo 4);

- İstanbul'un yine tek başına bir küme oluşturduğu,

- Ege Bölgesinin homojen yapısını korurken İzmir ilinin yine bu kümeden ayrıldığı,

- Karadeniz Bölgesindeki homojenliğin arttığı ve Trabzon ile Samsun illerinin mekânsal yakınlığa sahip diğer iller ile aynı kümede yer aldığı,

- Güneydoğu Anadolu Bölgesindeki homojenliğin bozularak TRC2 (Şanlıurfa alt bölgesi) ve TRC3'ün (Mardin alt bölgesi) iki farklı küme oluşturduğu,

- TRB2 Van alt bölgesinde, Van ilinin tek başına küme oluşturduğu görülmektedir.

2018 y1lı verilerine göre oluşan kümeler incelendiğinde ise sosyo-demografik yapı açısından (Tablo 3, Tablo 4);

- İstanbul'un tek başına küme oluşumunun devam ettiği,

- İzmir ilinin, mekânsal yakınlığa sahip illerle aynı küme içinde yer aldı $\breve{1}$,

- Karadeniz bölgesinde 2006 yılındaki kümelenmeye benzerliğin arttığı; mekânsal yakınlığa sahip illerin aynı kümede yer alırken, Samsun ve Trabzon'dan farklı olarak Çankırı'nın da bu kümelerden ayrıldığı,

- Güneydoğu Anadolu Bölgesinde TRC1 (Gaziantep Adıyaman) alt bölgesi hariç bölgede 2006 yılındaki homojen yapının tekrar oluştuğu,

- Doğu Anadolu bölgesi Erzurum alt bölgesinin (TRA1) homojen yapısının bozulduğu ve Erzurum ilinin kümeden ayrıldığı görülmektedir. b) Ekonomik kümeleme; ekonomik yönden kırsallığı anlatan 14 değişken ile yapılan kümeleme analizinin ANOVA tablolarına göre; "ülke içindeki ihracat" değişkenini -F değerine görekümelerin belirlenmesinde en önemli değişkendir. Yapılan kümeleme analizlerinde yalnızca 2012 (sig.0.210>0.05) ve 2018 (sig.0.907>0.05) y1llarına ait "hektara düşen hayvan sayısı" değişkeninin anlamsız olduğu görülmektedir. Anlamsız değişkenin çıkarılması sonucu kümeleme analizi tekrarlanmış olup sonuçları Tablo 5 'te gösterilmiştir.

Kırsallığın ekonomik yapısına ilişkin değişkenlerle üretilen kümeleme haritalarında 2006 verilerine göre ülkenin doğu ve batı bölgeleri arasındaki ayrım / farklılaşma dikkat çekicidir. Bir nevi ülkenin diyagonal bir aks ile bölünmesi söz konusudur (Tablo 4, Tablo 5).

- İstanbul ve Şanlıurfa'nın tek başına birer küme oluşturduğu,

- Doğu Marmara'nın bir kısmı ile Ankara'nın süreklilik gösteren bir kümede yer aldığı,

- Güney bandında Antalya ve Mersin illerinin ayrı bir küme oluşturduğu,

- Güneydoğu, Doğu Anadolu, Doğu Karadeniz ve İç Anadolu bölgesinin bir bölümünün (TR72) içinde bulunduğu alanın homojen bir ekonomik yapıdan oluştuğu; Rize, Gaziantep, Şanlıurfa illerinin bu yapıdan farklılaştığı görülmektedir.

2012 y1lı verilerine göre oluşan ekonomik kümeler incelendiğinde (Tablo 4, Tablo 5);

- Ülke genelinde 2006 yılındaki doğu batı ayrımının devam ettiği,

- İstanbul, Van ve Antalya illerinin tek başına bir küme oluşturduğu,

- Bursa ve Kocaeli'nin benzerlik göstererek ülke içinde farklı bir kümede yer aldığı,

- Gaziantep-Zonguldak hattının batısındaki illerin çoğunun aynı kümede yer aldığı,

- Şanlıurfa ilinin bu dönemde alt bölgesindeki illerle aynı kümede bulunduğu,

- Ege Bölgesinin bu dönemde iki farklı kümeden oluştuğu; İzmir ilinin Ankara, Konya, Mersin, Adana gibi iller ile aynı kümede yer aldığı görülmüştür.

2018 yılı verilerine göre oluşan kümeler incelendiğinde ise (Tablo 4, Tablo 5);

- İstanbul ilinin yine tek başına bir küme oluşturduğu,

- Gaziantep-Zonguldak hattının batısında yer alan birçok ilin 
Tablo 5. Türkiye illeri kırsallığının ekonomik açıdan kümelenmesi. Table 5. Economic clustering of Turkey provinces rurality.

\begin{tabular}{|c|c|c|}
\hline & Küme ve III Sayısı & Kümede Yer Alan IIller \\
\hline 2006 yılı & $\begin{array}{l}\text { 2. Küme } \\
\text { (20 il) } \\
\text { 3. Küme } \\
\text { (4 il) } \\
\text { 4. Küme } \\
\quad(4 \text { il) } \\
\text { 5. Küme } \\
\quad(1 \text { il) } \\
\text { 6. Küme } \\
\text { (1 il) }\end{array}$ & $\begin{array}{l}\text { Adıyaman, Afyonkarahisar, Ağrı, Aksaray, Ardahan, Artvin, Bartın, Batman, Bayburt, Bingöl, Bitlis, Bolu, Burdur, Çankırı, Çorum, Di- } \\
\text { yarbakır, Düzce, Elazığ, Erzincan, Erzurum, Giresun, Gümüşhane, Hakkâri, Iğdır, Kahramanmaraş, Karabük, Kars, Kastamonu, Kayseri, } \\
\text { Kırıkale, Kırklareli, Kütahya, Malatya, Mardin, Muş, Nevşehir, Niğde, Ordu, Osmaniye, Siirt, Sinop, Sivas, Şırnak, Tekirdağ, Trabzon, } \\
\text { Tunceli, Uşak, Van, Yalova, Yozgat, Zonguldak } \\
\text { Adana, Amasya, Ankara, Antalya, Balıkesir, Bilecik, Çanakkale, Edirne, Eskişehir, Gaziantep, Hatay, Isparta, Karaman, Kırşehir, Kilis, } \\
\text { Mersin, Muğla, Rize, Samsun, Tokat } \\
\text { Aydın, İzmir, Konya, Manisa } \\
\text { Bursa, Denizli, Kocaeli, Sakarya }\end{array}$ \\
\hline 2012 yılı & $\begin{array}{l}\text { 1. Küme } \\
\text { (48 il) } \\
\text { 2. Küme } \\
\text { (23 il) } \\
\text { 3. Küme } \\
\text { (6 il) } \\
\text { 4. Küme } \\
\text { ( } 2 \text { il) } \\
\text { 5. Küme } \\
\text { (1 il) } \\
\text { 6. Küme } \\
\text { (1 il) }\end{array}$ & $\begin{array}{l}\text { Adıyaman, Afyonkarahisar, Ağrı, Aksaray, Amasya, Ardahan, Artvin, Aydın, Balıkesir, Bartın, Batman, Bayburt, Bingöl, Bitlis, Burdur, } \\
\text { Çankırı, Çorum, Diyarbakır, Edirne, Elazığ, Erzincan, Erzurum, Giresun, Gümüşhane, Hakkâri, Iğdır, Isparta, Kars, Kastamonu, Kırıka- } \\
\text { le, Kilis, Malatya, Mardin, Muğla, Muş, Nevşehir, Niğde, Ordu, Samsun, Siirt, Sinop, Sivas, Şanlıurfa, Şırnak, Tokat, Trabzon, Tunceli, } \\
\text { Yozgat } \\
\text { Bilecik, Bolu, Çanakkale, Denizli, Düzce, Eskişehir, Gaziantep, Hatay, Kahramanmaraş, Karabük, Karaman, Kayseri, Kırklareli, Kırşehir, } \\
\text { Kütahya, Manisa, Osmaniye, Rize, Sakarya, Tekirdağ, Uşak, Yalova, Zonguldak } \\
\text { Adana, Ankara, Antalya, İzmir, Konya, Mersin } \\
\text { Bursa, Kocaeli } \\
\text { Van } \\
\text { İstanbul }\end{array}$ \\
\hline 2018 yılı & $\begin{array}{l}\text { 1. Küme } \\
\text { (43 il) } \\
\text { 2. Küme } \\
\text { (15 il) } \\
\text { 3. Küme } \\
\text { (16 il) } \\
\text { 4. Küme } \\
\text { ( } 3 \text { il) } \\
\text { 5. Küme } \\
\text { (3 il) } \\
\text { 6. Küme } \\
(1 \text { il) }\end{array}$ & $\begin{array}{l}\text { Adana, Adıyaman, Afyonkarahisar, Amasya, Antalya, Artvin, Balıkesir, Bartın, Bingöl, Bolu, Burdur, Çanakkale, Çankırı, Çorum, } \\
\text { Diyarbakır, Düzce, Edirne, Elazığ, Erzincan, Erzurum, Giresun, Gümüş̧hane, Isparta, Kahramanmaraş, Kastamonu, Kırklareli, Kırşehir, } \\
\text { Konya, Kütahya, Malatya, Mersin, Muğla, Nevşehir, Ordu, Osmaniye, Samsun, Sivas, Şırnak, Tokat, Trabzon, Tunceli, Uşak, Yozgat } \\
\text { Ankara, Bilecik, Bursa, Denizli, Eskişehir, Gaziantep, Hatay, İzmir, Karabük, Kayseri, Kocaeli, Sakarya, Tekirdağ, Yalova, Zonguldak }\end{array}$ \\
\hline
\end{tabular}

*Altı çizili iller kümeleme analizinde en düşük "distance değerine sahip olan ve bulunduğu kümeyi en iyi temsil eden illerdir.

bu dönemde ekonomik bağlamda hattın doğusunda yer alan iller ile benzeştiği,

- Karaman ve Siirt ile Rize, Manisa ve Aydın'ın aynı ekonomik kümede,

- Doğu ve Batı bölgeleri arasında net olarak gözlemlenen ayrımın azaldığı,

- Güney bandında Antalya ve Mersin illerinin 2006 kümelenmesine benzer şekilde ayrı bir küme oluşturduğu görülmektedir.

c) Fiziksel kümeleme; İllerin fiziksel çevre değişkenleri açısından kırsallığının kümelenmesi aşamasında 2006, 2012, 2018 yılları için 12 fiziksel çevre değişkeni ile yapılan kümeleme analizi sonuçları Tablo 6'da gösterilmiştir. Yapılan kümeleme analizi ANOVA tablolarına göre; kümelerin belirlenmesinde en etkili değişken 2006 ve 2018 yıllarında "il içindeki şehir yapısı oranı" -F değerine göre-, 2012 yılında ise "il içindeki yapay alanların oranı"dır. Her üç yıl için yapılan kümeleme analizi ANOVA tabloları güven düzeyine göre $($ sig.<0.05) kullanılan tüm değişkenlerin anlamlı olduğu görülmüştür (Tablo 6).

Türkiye illeri kırsalının fiziksel yapısına ilişkin değişkenlerle üretilen kümeleme haritalarında, 2006 yılı verilerine göre ülke genelinde illerin genellikle 1 . ve 2 . kümede bir arada bulunduğu dikkat çekmektedir (Tablo 4, Tablo 6). Diğer kümelerde ise; 
- İstanbul'un (TR10) tek başına 6. kümede,

- Doğu Karadeniz Bölgesinde aynı alt bölgede (TR90) yer alan Trabzon ve Ordu illeri de benzer fiziksel yapıya sahip olarak 5. kümede,

- İç Anadolu bölgesinde Ankara, Konya ve Sivas illeri 4. kümede

- Son olarak da Hatay, Aydın, İzmir, Yalova, Kocaeli ve Zonguldak illerinin 3. kümede yer aldığı görülmektedir.

2012 yılı verilerine göre oluşan kümeler incelendiğinde ülke genelinde illerin ağırlıklı olarak 1. kümede yer aldığ görülmektedir (Tablo 4, Tablo 6). Fiziksel kümeleme sonucunda;

- İstanbul'un tek başına yine bir küme oluşturduğu,

- 2006 yilında 5. kümede yer alan Trabzon ve Ordu illerine aynı alt bölgede yer alan Rize ilinin de eklendiği,
- 4. kümeyi Doğu Anadolu Bölgesinde yer alan illerin (Erzurum, Kars, Ağrı, Muş, Bitlis, Van) birçoğu ile Karadeniz Bölgesindeki Kastamonu ilinin oluşturduğu,

- 2006 yılında 3. kümede yer alan illerin komşu illerinin de eklenmesiyle kümenin genişlediği görülmektedir.

2018 yılı verilerine göre oluşan kümeler incelendiğinde ülke genelinde illerin yine ağırlıklı olarak 1. Kümede yer aldığ 1 görülmektedir (Tablo 4, Tablo 6). Ayrıca;

- İstanbul ilinin tek başına bir küme oluşturmaya devam ettiği,

- 5. kümede yer alan illerin sayısının arttığı, ancak 2006 ve 2012 yılında bu kümede bulunan Trabzon ve Ordu illerinin artık 3. kümede yer aldığı,

- 4. fiziksel yapı kümesini ise yine ağırlıklı olarak Doğu

Tablo 6. Türkiye illeri kırsallığının fiziksel çevre açısından kümelenmesi

Table 6. Physical environment clustering of Turkey provinces rurality

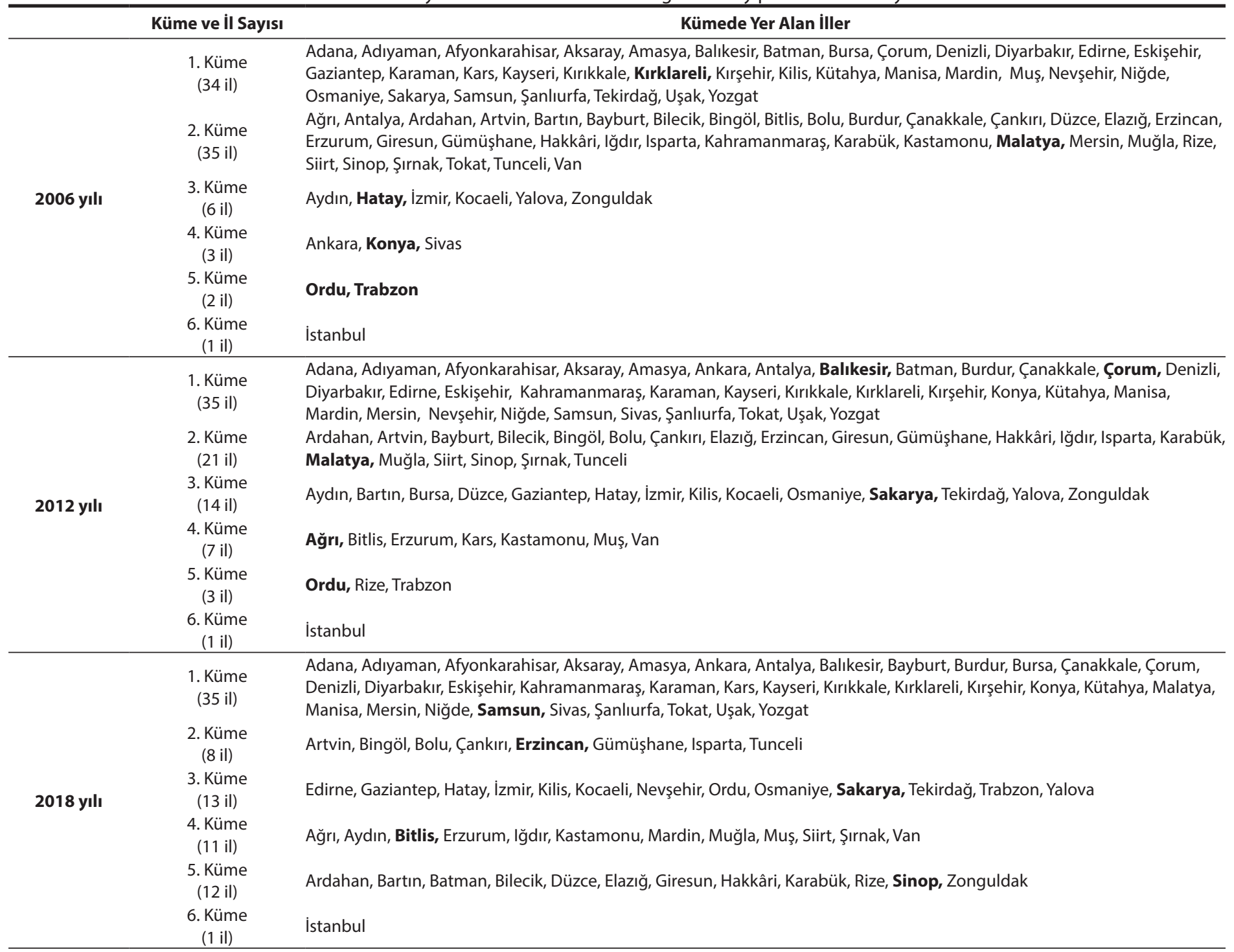

*Altı çizili iller kümeleme analizinde en düşük "distance değerine sahip olan ve bulunduğu kümeyi en iyi temsil eden illerdir. 
Anadolu Bölgesi yer alan illeri oluştururken kümede Kastamonu, Aydın ve Muğla illeri de yer aldı ğı görülmektedir.

\section{TARTIŞMA VE SONUÇ}

Türkiye'de kırsal alan ve yerleşmelerin kırsallık düzeyleri sosyo-demografik, ekonomik, fiziksel ve ekolojik yönlerden çeşitlilik göstermektedir. Tek bir değişken ile tanımlanamayacak kırsallık olgusunun ele alındığı çalışmada seçilmiş göstergeler yardımıla illerin benzerliklerine göre kümelenmesi ve kümelerin zaman içindeki değişimlerinin değerlendirilmesi yapılmıştır. Mevcut veri varlığı değerlendirilerek yapılan çalışma kırsallığın zaman içindeki değişimini aktarma hedefi taşınmasına karşın yeni bir kırsallık sınıfı tanımı iddiası barındırmamaktadır.

Çok boyutlu kırsallık göstergeleri ile yapılan kümeleme ve il-alt bölge-bölge düzeyindeki mekânsal değerlendirmeler sonucunda ülkenin sosyo-demografik, ekonomik, fiziksel bağlamlarda karakteristik özellikler gösterdiği, 2006 yılından bugüne ülkede ekonomik yapıda hissedilen doğu-batı arasındaki keskinliğin zaman içerisinde kırıldığı görülmüştür. Bu kırılmalara veya dönemler arasındaki değişimlere neden olan faktörlerin kırsallığın değerlendirildiği üç boyut özelindeki zamana bağlı farklılıkları şöyledir (Tablo 7);

Sosyo-demografik bağlamda; "il içindeki aktif nüfus oranının" yüksek ve "kırsal nüfus oranının" düşük olduğu iller 2006 yılında aynı kümede (küme-2) ve özellikle ülkenin güneybatı bölümünde yer almaktadır. 2012 yılında özelliklerini büyük ölçüde koruyan bu küme 2018 yılında bazı illerin büyükşehir statüsüne geçmesi nedeniyle değişmiştir. Bugün küme-2 kırsallık oranın düşük olmasına karşın aktif nüfus barındıran büyükş̧ehirlerden oluşmaktadır. "Genç bağımlılığın" ve "ortalama hane büyüklügünün" yüksek olduğu Küme-1 ülkenin Güneydoğusunda homojen bir bölge özelliği göstermektedir. 2006'da 3. Kümede yer alan Adiyaman $(\% 16,35)$, Kars $(\% 21,80)$ ve Bingöl $(\% 22,49)$ illerinin “ortalama hane büyüklügündeki” artış, 2012 yılında bu illerin de Küme-1'de yer almasına neden olmuştur. 2012 yılında hem "genç bağımlılık oranının" hem de "köy nüfusunun" yüksek olduğu Şanlıurfa, Van ve Diyarbakır illeri Hatay ile ayrı bir küme oluşturmuşlardır. 6360 sayılı yasa sonrasında ise Diyarbakır, Şanlıurfa ve Van illerinin tekrar küme-1 özelliği gösterdiği görülmektedir. Ayrıca; 2018 yılında ülke içindeki "yı1lık nüfus artış hızı" en yüksek olan Çankırı $(150,81)$ diğer kümelerden farklı bir sosyo-demografik yapı göstermektedir (Tablo 7).
Ekonomik bağlamda; yenilikçi bir tarımsal üretimi anlatan "organik üretim oranı" ve "organik üretimde bulunan çiftçi sayısı" Küme-5'in oluşmasında etkili olmuş; 2006 yılında Şanlıurfa (21,84), 2012 y1lında Van (16,73) ve 2018 yllında Aydın $(14,87)$ ve Manisa illeri ülke içindeki organik üretim oranında ilk sırada yer almıştır. "Tarımsal üretim oranı" ve "örtü altı tarım oranı" değişkenlerine göre şekillenen Küme-4'de Antalya ve Mersin illeri yer almaktadır. 2012 yılında Antalya ilinin tarımsal üretimdeki artış $(\% 28,13)$ ile Mersin ili üretimindeki azalış $(\% 10,38)$ bu dönemde kümede tek Antalya ilinin yer almasına neden olmuştur. "Ülke içi ve kişi başına düşen ithalat ve ihracat oranlarından" büyük bir pay alan İstanbul ili her üç dönemde de Küme-6'da tek başına yer almaktadır. İstanbul ilinden $(8,63)$ sonra en fazla kişi başı ithalat oranına sahip Küme 3'ün oluşumunda ise birçok değişken etkili olurken; bu kümede yer alan illerin ekonomisinin sanayi sektörü odaklı olduğu görülmektedir (Tablo 7).

Fiziksel çevre bağlamında; küme 6'in oluşmasında en etkili değişkenlerin "il içindeki şehir yapısı, sürekliliği olmayan kırsal yerleşim alanı oranı ve il içindeki yapay alanlar oranı" değişkenleri olduğu ve yoğun şehirsel doku olarak adlandırabileceğimiz bu kümenin diğer boyutlarda da olduğu gibi tek temsilcisi İstanbul ilidir. "İle düşen köy yolu" ile "kara ve demir yolu" Küme-5'in oluşmasında etkilidir. Özellikle Karadeniz illerinde zor topoğrafik koşullar illerdeki ulaşım bağlantılarının yoğunluğunu artıran bir etmen olup, 2006 ve 2012 yillarında bu küme net bir biçimde ortaya çıkmaktadır. Trabzon $(\% 3,70)$ ya da Ordu $(\% 3,21)$ köy yol ağı ile ülkede ilk sıralarda yer almaktadır. Küme 2'nin oluşmasında "orman-yarı doğal alanlar" ve "tarımsal alanlar(-)" değişken değerleri etkili olurken bakir, doğal alanların yoğun olduğu görece az şehirleşmiş illerin oluşturduğu bir küme olarak karşımıza çıkmaktadır. Örneğin, Türkiye genelinden bu oran \%53 iken Artvin ilinde bu oran \%86'dır (Tablo 7).

Sonuç olarak; kent ve kırsal bölgelerin bütünleşik olarak yeniden değerlendirilmesini öngören bugünün mekânsal gelişim politikaları açısından yerleşmelerin çok yönlü ve çok değişkenli süreçler ile ele alınması gerekmektedir. Bu nedenle çalışmanın il düzeyinde zamana bağlı yapılan karşılaştırmalarının yanı sıra bölgeler içinde var olan homojenlik/heterojenlik konusunda planlama karar ve politikaları üretmeye yararlı olacağı düşünülmektedir. 


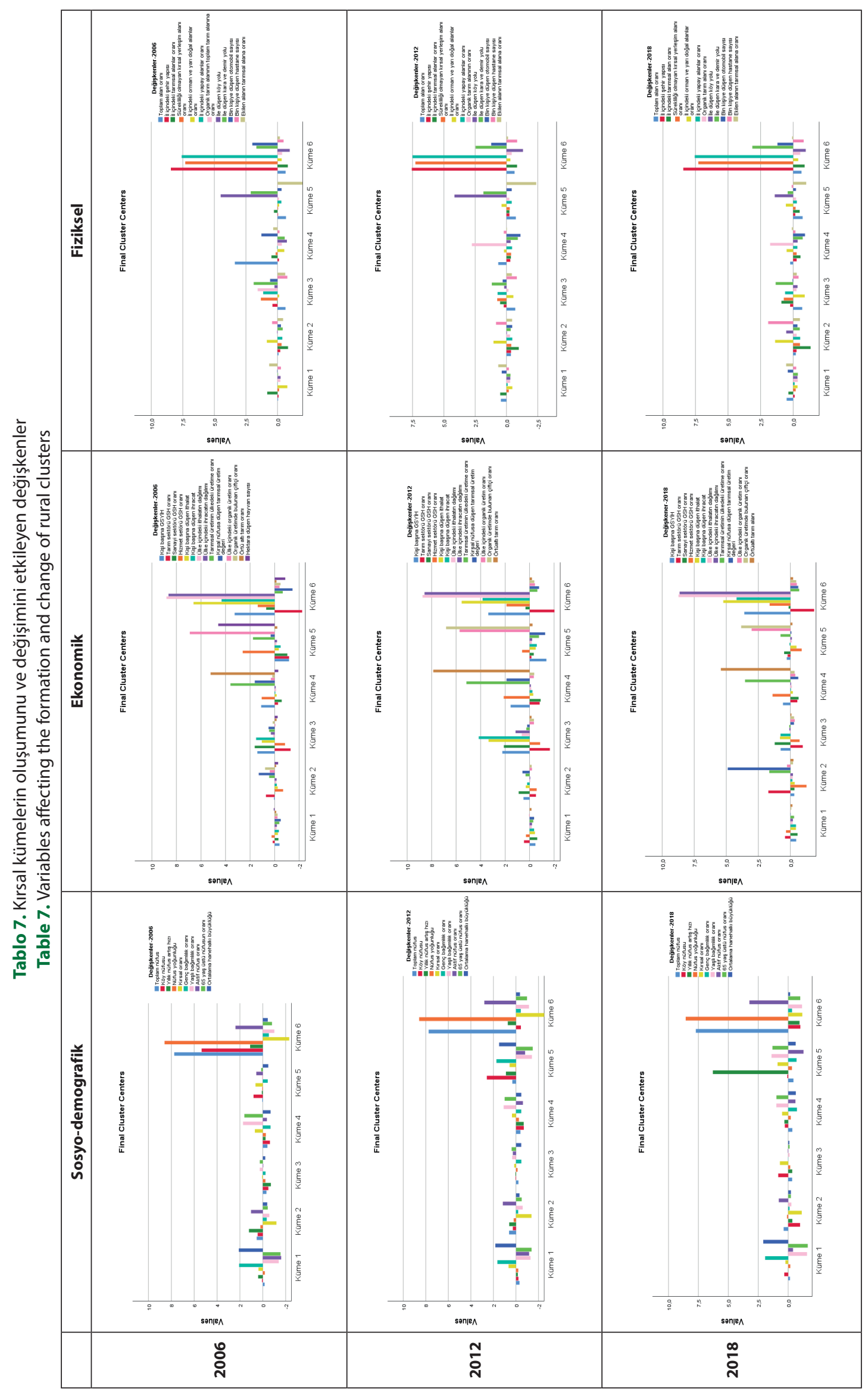


Hakem Değerlendirmesi: Dıș bağımsız.

Çıkar Çatışması: Yazarlar çıkar çatışması bildirmemiştir.

Finansal Destek: Yazarlar bu çalışma için finansal destek almadığını beyan etmiştir.

Peer-review: Externally peer-reviewed.

Conflict of Interest: The authors have no conflict of interest to declare.

Grant Support: The authors declared that this study has received no financial support.

\section{KAYNAKÇA/REFERENCES}

Akder, A. H. (2003). Linking agricultural statistics to other data sources for analysing rural indicators of social well-being and equity, 8th IWG. AGRI Seminar, Perspectives for Agriculture and Rural Indicators and Sustainability, Château de la Muette, Paris, 21-22 November 2002 Statistics Directorate National AccountsAgriculture.

European Commission. Committee on Spatial Development. (1999). ESDP-European Spatial Development Perspective: Towards Balanced and Sustainable Development of the Territory of the European Union: Agreed at the Informal Council of Ministers Responsible for Spatial Planning in Potsdam, May 1999. Office for Official Publications of the European Communities.

Ballas, D., Kalogeresis, T., \& Labrianidis, L. (2003). A comparative study of typologies for rural areas in Europe, 43rd Congress of the European Regional Science Association: "Peripheries, Centres, and Spatial Development in the New Europe”, 27th - 30th August 2003, Jyväskylä, Finland

United Nations. (1969). Growth of the World's Urban and Rural Population, 1920-2000.

Bengs, C., \& Schmidt-Thomé, K. (2005). Urban-rural relations in Europe: ESPON 1.1. 2. Final report.

Blunden, J. R., Pryce, W. T. R., \& Dreyer, P. (1998). The classification of rural areas in the European context: An exploration of a typology using neural network applications. Regional Studies, 32(2), 149 -160 .

Boscacci, F., Arcaini, E., Boscacci, F., Camagni, R., Capello, R., \& Porro, G. (1999). A typology of rural areas in Europe. Study Programme on European Spatial Planning of the European Commission", Milan: Milan Polytechnic.

Cloke, P. J. (1977). An index of rurality for England and Wales. Regional Studies, 11(1), 31-46.

Cloke, P., \& Edwards, G. (1986). Rurality in England and Wales 1981: a replication of the 1971 index. Regional Studies, 20(4), 289-306.

Coombes, M., \& Raybould, S. (2004). Finding work in 2001: urbanrural contrasts across England in employment rates and local job availability. Area, 36(2), 202-222.

Çakmak, Z., Uzgören, N., \& Keçek, G. (2005). Kümeleme analizi teknikleri ile illerin kültürel yapılarına göre sınıflandırılması ve değişimlerin incelenmesi, Dumlupınar Üniversitesi Sosyal Bilimler Dergisi, (12), 15-36.
Davoudi, S., \& Stead, D. (2002). Urban-rural relationships: an introduction and brief history. Built Environment, 28(4), 269-277.

Teşkilatı, D. P. (1982). Türkiye'de yerleşme merkezlerinin kademelenmesi: ülke yerleşme merkezleri sistemi. Devlet Planlama Teşkilatı Kalkınmada Öncelikli Yöreler Başk, Ankara.

Teşkilatı, D. P. (2004). İçelerin sosyo-ekonomik gelişmişlik sıralaması araştırması. Devlet Planlama Teşkilatı, Ankara.

ESPON, I. (2004). Potentials for polycentric development in Europe. https://www.espon.eu/sites/default/files/attachments/fr-1.1.1_ revised-full_0.pdf

EUROSTAT, (2005). Nomenclature of territorial units for statistics NUTS (Luxemburg: Statistical Regions of Europe).

EUROSTAT, (2010). A revised urban-rural typology, Eurostat Regional Yearbook, 239-253.

Everitt, B. (1993) Cluster analysis for applications, Academic Press, New York

Geray, C. (2009). Bölgesel gelişme için planlama ve örgütlenme. Ankara Üniversitesi SBF Dergisi, 52(01).

Gülümser, A. A., Baycan Levent, T., \& Nijkamp, P. (2011). Türkiye'nin kırsal yapısı: AB düzeyinde bir karşılaştırma. ITÜDERGISİ/a, 9(2).

Nijkamp, P., Levent, T. B., \& Gulumser, A. A. (2006). Turkey's rurality: A comparative analysis at the EU level. 46th Congress of the European Regional Science Association: "Enlargement, Southern Europe and the Mediterranean", August 30th - September 3rd, 2006, Volos, Greece.

Hajizadeh, E., Ardakani, H. D., \& Shahrabi, J. (2010). Application of data mining techniques in stock markets: A survey. Journal of Economics and International Finance, 2(7), 109-118.

Hugo, G., Champion, A., \& Lattes, A. (2003). Toward a new conceptualization of settlements for demography. Population and Development Review, 29(2), 277-297.

Labrianidis, L. (2006). Human capital as the critical factor for the development of Europe's rural peripheral areas. The New European Rurality: Strategies for Small Firms, 41-59.

Leavy, A., McDonagh, P., \& Commins, P. (1999). Public policy trends and some regional impacts. Teagasc.

Van Leeuwen, E. (2015). Urban-rural synergies: An explorative study at the NUTS3 Level. Applied Spatial Analysis and Policy, 8(3), 273-289.

Organisation for Economic Co-operation and Development (OECD). Group of the Council on Rural Development. (1993). What future for our countryside?: a rural development policy. Organisation for Economic Co-operation and Development.

Organisation for Economic Co-operation and Development. (1994). Creating rural indicators for shaping territorial policy. OECD.

Organization for Economic Cooperation and Development. (1996). Territorial indicators of employment: focusing on rural development. OECD.

Organization for Economic Cooperation and Development. (2011). Regional typology report. Directorate for public governance and territorial development. Our urbanizing World, No:2014/3 (OECD), 
Öğdül, H. G. (2010). Urban and rural definitions in regional context: A case study on Turkey. European Planning Studies, 18(9), 15191541.

Pettersson, Ö. (2001). Microregional fragmentation in a Swedish county. Papers in Regional Science, 80(4), 389-409.

Pizzoli, E., \& Gong, X. (2007, October). How to best classify rural and urban. In ponencia presentada en la Fourth International Conference on Agriculture Statistics, 22-24.

P1zzol1, E. (2017). Rural development indicators for regions with different degrees of «rurality»: a statıstical study, 1-10.

Punj, G., \& Stewart, D. W. (1983). Cluster analysis in marketing research: Review and suggestions for application. Journal of Marketing Research, 20(2), 134-148.

Gazete, T. R. (2012). On üç ilde büyükşehir belediyesi ve yirmi altı ilçe kurulması ile bazı kanun ve kanun hükmünde kararnamelerde değişiklik yapılmasına dair kanun. Kabul Tarihi, (28489).

Scholz, J., \& Herrmann, S. (2010). Rural Regions in Europe. A new typology showing the diversity of European rural regions: RUFUS Discussion Paper. http://citeseerx.ist.psu.edu/viewdoc/ download?doi=10.1.1.527.4514\&rep=rep1\&type $=$ pdf

Shih, M. Y., Jheng, J. W., \& Lai, L. F. (2010). A two-step method for clustering mixed categroical and numeric data. Tamkang Journal of Science and Engineering, 13(1), 11-19.

Sotte, F. (2003). An Evolutionary approach to rural development. Some Lessons for The Policymaker, Associazione Alessandro Bartola, Collana Appunti, No. 3, Ancona, Italy.
Tatlıdil, H. (1992). Çok değişkenli istatistiksel analiz. Ankara: Hacettepe Üniversitesi Yayınları. Ankara.

Tekin, B. (2018). Ward, k-ortalamalar ve iki adımlı kümeleme analizi yöntemleri ile finansal göstergeler temelinde hisse senedi tercihi. Balıkesir Üniversitesi Sosyal Bilimler Enstitüsü Dergisi, 21(40), 401-436.

TÜBİTAK. (2014). Koruma Odaklı Kırsal Alan Planlaması: Bir Model Önerisi Projesi Final Raporu, Proje No: 108G173, Trabzon.

Türkiye İstatistik Kurumu (TÜİK). (2019). Bölgesel istatistikler veri seti. https://biruni.tuik.gov.tr/bolgeselistatistik/ Erişim: Ağustos 2019.

United Nations. Economic Commission for Europe, \& Statistical Office of the European Communities. (2007). Rural Households' Livelihood and Well-being: Statistics on Rural Development and Agriculture Household Income. United Nations Publications.

Wagstaff, K., Cardie, C., Rogers, S., \& Schrödl, S. (2001). Constrained k-means clustering with background knowledge. Proceedings of the Eighteenth International Conference on Machine Learning, 577584.

Vincze, M., \& Mezei, E. (2011). The increase of rural development measures efficiency at the micro-regions level by cluster analysis. A Romanian case study. Eastern Journal of European Studies, 2(1), 13.

Zheliazkov, G., Zaimova, D., Genchev, E., \& Toneva, K. (2015). Cluster development in rural areas. Economics of Agriculture, 73-93. 
